\title{
A Pervasive Economic Fallacy in Assessing the Cost of Public Funds
}

\section{CIRANO}

Allier savoir et décision

MARCEL BOYER 


\section{$\checkmark$ CIRANO Knowledge into action}

Center for Interuniversity Research and Analysis on Organizations

The purpose of the Working Papers is to disseminate the results of research conducted by CIRANO research members in order to solicit exchanges and comments. These reports are written in the style of scientific publications. The ideas and opinions expressed in these documents are solely those of the authors.

Les cahiers de la série scientifique visent à rendre accessibles les résultats des recherches effectuées par des chercheurs membres du CIRANO afin de susciter échanges et commentaires. Ces cahiers sont rédigés dans le style des publications scientifiques et n'engagent que leurs auteurs.

CIRANO is a private non-profit organization incorporated under the Quebec Companies Act. Its infrastructure and research activities are funded through fees paid by member organizations, an infrastructure grant from the government of Quebec, and grants and research mandates obtained by its research teams.

Le CIRANO est un organisme sans but lucratif constitué en vertu de la Loi des compagnies du Québec. Le financement de son infrastructure et de ses activités de recherche provient des cotisations de ses organisations-membres, d'une subvention d'infrastructure du gouvernement du Québec, de même que des subventions et mandats obtenus par ses équipes de recherche.

\section{CIRANO Partners - Les partenaires du CIRANO}

Corporate Partners - Partenaires corporatifs

Autorité des marchés financiers

Bank of Canada

Bell Canada

BMO Financial Group

Business Development Bank of Canada

Caisse de dépôt et placement du Québec

Desjardins Group

Énergir

Hydro-Québec

Innovation, Science and Economic Development Canada

Intact Financial Corporation

Manulife Canada

Ministère de l'Économie, de la Science et de l'Innovation

Ministère des finances du Québec

National Bank of Canada

Power Corporation of Canada

PSP Investments

Rio Tinto

Ville de Montréal

\section{Academic Partners - Partenaires universitaires}

Concordia University

École de technologie supérieure

École nationale d'administration publique

HEC Montréal

McGill University

National Institute for Scientific Research

Polytechnique Montréal

Université de Montréal

Université de Sherbrooke

Université du Québec

Université du Québec à Montréal

Université Laval

CIRANO collaborates with many centers and university research chairs; list available on its website. Le CIRANO collabore avec de nombreux centres et chaires de recherche universitaires dont on peut consulter la liste sur son site web.

(C) December 2020. Marcel Boyer. All rights reserved. Tous droits réservés. Short sections may be quoted without explicit permission, if full credit, including (C) notice, is given to the source. Reproduction partielle permise avec citation du document source, incluant la notice C.

The observations and viewpoints expressed in this publication are the sole responsibility of the authors; they do not necessarily represent the positions of CIRANO or its partners. Les idées et les opinions émises dans cette publication sont sous l'unique responsabilité des auteurs et ne représentent pas nécessairement les positions du CIRANO ou de ses partenaires. 


\title{
A Pervasive Economic Fallacy in Assessing the Cost of Public Funds
}

\author{
Marcel Boyer *
}

\begin{abstract}
Résumé
In the assessment of the cost of public funds, there is a pervasive economic fallacy, which is frequently repeated by officials in both the private and public sectors as well as in academia: since the cost of borrowing is higher for a private sector firm than it is for a public sector firm, the cost of carrying out an activity (investment, production, distribution, provision of goods and services) will necessarily be lower ceteris paribus in the public sector than in the private sector. The statement is erroneous because part of the government's cost of borrowing is hidden from the casual observer of interest rates or yields. The all-inclusive borrowing cost, more generally the all-inclusive cost of capital, is the same for both the public and private sector. I discuss four specific real cases where the error is present, the first three more succinctly and the last more more extensively: the Quebec Generations Fund; the Québec CDPQ Infra REM project; the Infrastructure Ontario methodology to assess the riskiness of costs; the BC Hydro's Site C hydroelectric megaproject. I discuss also a general fifth case, namely governement support programs for business (grants, loans, guarantees, subsidies, etc.). Those are often justified on the fallacious claim that the cost of financing is samller for the government than for the private sector. I propose an auction process by which the true cost of business support programs could be made transparent. I conclude with an appeal for a more rigorous use and management of public fiunds. I expect that miscalculation, misinformation, mismanagement, and fallacious analysis will backfire, as always.
\end{abstract}

Keywords/Mots-clés: Cost of Capital, Public Debt, Site C Project, Generations Fund, REM, Infrastructure Ontario

\footnotetext{
* Ph.D., O.C., FRSC. Emeritus Professor of Economics, Université de Montréal; Bell Canada Professor of Industrial Economics (2000-2008), Université de Montréal; Jarislowsky-SSHRC-NSERC Professor of International Competition (1993-2000), Polytechnique-Montréal; Associate Member, TSE \& IAST; Fellow, CIRANO \& C.D. Howe Institute; University Affiliate, Analysis Group.
} 


\section{INTRODUCTION}

At a time when governments are on the verge of investing vast sums of money, from taxation and borrowing, to boost infrastructures and to support businesses badly afected by the COVID pandemy, it is useful to revisit the cost of public funds. If decisions must be based on a proper balancing of benefis and costs, it is imperative that the latter, as well as the former, be properly assessed. This paper concentrates on the cost of money, clearly a central element of investment decisions.

The assessment of the cost of public funds for public invetment projets is the source of a significant economic fallacy that is frequently repeated by officials in both the private and public sectors. In its simplest form, the error appears as follows: Since the cost of borrowing or financing is higher for a private sector firm or organisation than it is for a public sector firm or organisation, the cost of carrying out an activity (production, distribution, the provision of goods and services) will necessarily be lower in the public sector than in the private sector.

Although it is generally accepted, and indeed observed, that governments can borrow at lower rates than private or competitive sector organizations, the error in the above argument is that part of the government's cost of borrowing is hidden from the casual observer of interest rates or yields.

Let us consider two firms, one in the government sector and the other in the competitive sector, both of which produce, distribute, and supply the same goods and / or services. The cost to the government sector firm of obtaining credit or capital is lower than that offered to the private or competitive sector firm. This is because the former is less risky for lenders, who therefore require a lower rate of return. But why is the cost of financing lower for a government sector firm engaged in the same processes and activities, presumably using the same technology and factors of production, and therefore exposed to the same risk factors? Why, then, would it be less risky to lend to a government enterprise?

This is because the government-sector enterprise belongs to the government, which is ultimately responsible for it and has the right and ability to raise additional taxes to reimburse its lenders if necessary: that is, if its activities and / or projects fail, or, more generally, fall short of expectations. Private- or competitive-sector firms do not have that option, which provides the rationale for a higher interest rate by lenders or investors. However, from the point of view of the citizens who are the final customers and taxpayers, the right and power of the government to literally withdraw money from their bank accounts to cover financial difficulties does have a price: it is the value today of conferring on the government the right to require and obtain additional funds from them to cover what may turn out to be bad or unprofitable projects, ex-post. 
Given this loan repayment guarantee, the providers of funds will require only a small risk premium where appropriate, regardless of why or for what projects the government is borrowing and regardless of their contribution to the portfolio risk of the government's diversified portfolio of projects and activities.

This guarantee allows the government to offer a transaction that is essentially risk-free for lenders, but potentially very risky for taxpayers. The error lies in that fact that this taxpayersupported cost is dismissed and swept under the carpet.

The differential in interest rates or returns paid on funds raised by governmental organizations, on the one hand, and private- or competitive-sector organizations, on the other, is fundamentally equal to the value of the government's right and ability to raise additional funds from taxpayers as lenders and investors, even without their "consent." In other words, if the citizens were to grant private- or competitive-sector organizations in good financial standing the right and power to levy "taxes" if they were to find themselves in dire financial straits, these organizations would be able to raise capital on the same terms as the government.

Hence, the claim that the public sector can produce at lower costs because the government can pay lower interest rates on money it raises is an admittedly subtle, but nonetheless clear and unmistakable, illusion. ${ }^{1}$ The all-inclusive borrowing cost, more generally the all-inclusive cost of capital, is the same for both the public and private sector.

An example of this erroneous reasoning from someone in the private sector. According to an article published in La Presse on May 5, 2010, Bombardier President and CEO Pierre Beaudoin questioned the public-private partnership (PPP) model during a debate held at the Milken Institute in Santa Monica, California. He was quoted as saying that it costs companies much more than governments to borrow large sums of money and that the private sector is well placed to manage project costs and meet project deadlines, but not, as a rule, that it is better placed to finance projects. He continued to say that over a 20 -year period, a US\$1 billion project is likely to cost an additional US\$480 million if it is financed by the private sector rather than public authorities. ${ }^{2}$ He forgot to mention that public authorities do not incur a premium for the risk of failure. If such a failure occurs, they (or their taxpayers) will nevertheless cover the cost, which will likely be much higher than US\$480 million.

\footnotetext{
${ }^{1}$ For a more in-depth investigation of this issue, see Marcel Boyer, Éric Gravel, and Sandy Mokbel, "The Valuation of Public Projects: Risks, Cost of Financing and Cost of Capital," Commentary No. 388, C.D. Howe Institute (2013). https://www.cdhowe.org/sites/default/files/attachments/research_papers/mixed/Commentary \%20388 0.pdf

${ }^{2}$ See https://www.lapresse.ca/affaires/economie/quebec/201005/04/01-4277120-bombardier-sinterroge-sur-laviabilite-des-ppp.php and https://www.lapresse.ca/opinions/201005/07/01-4278358-financement-des-ppplerreur-de-pierre-beaudoin.php
} 
An example from academia. Christina Pazzanese in "Our Crumbling Infrastructure," Harvard Gazette, January 6, 2017, writes: "Some observers, like the New York Times columnist Paul Krugman, a liberal economist, have criticized Trump's private investment strategy as unnecessary, given the government's unmatched ability to borrow money on the cheap." ${ }^{3}$ Paul Krugman (laureate of the 2008 Nobel prize in economic science) contends himself in a column of The New York Times ${ }^{4}$.

"To understand what's going on, it may be helpful to start with what we should be doing. The federal government can indeed borrow very cheaply; meanwhile, we really need to spend money on everything from sewage treatment to transit. The indicated course of action, then, is simple: borrow at those low, low rates, and use the funds raised to fix what needs fixing"

In his reasoning, Krugman simply neglects the significant risk that taxpayers are supporting.

In the next four sections, I discuss four specific real cases where the error is present, the first three more succinctly and the last more extensively: the Quebec Generations Fund; the Québec CDPQ Infra REM project; the Infrastructure Ontario methodology to assess the riskiness of costs; the BC Hydro's Site C hydroelectric megaproject. I discuss also a general fifth case, namely governement support programs for business (grants, loans, guarantees, subsidies, etc.). Those are often justified on the fallacious claim that the cost of financing is smaller for the government than for the private sector. I propose an auction process by which the true cost of business support programs could be made transparent. I conclude with an appeal for a more rigorous use and management of public fiunds. I expect that miscalculation, misinformation, mismanagement, and fallacious analysis will eventually backfire, as always.

\section{THE GENERATIONS FUND}

During the 2018 Quebec election, the Quebec Liberal Party (QLP) announced its intention to use $\$ 10$ billion from the Generations Fund (GF) to pay down the debt at a rate of $\$ 2$ billion per year for five years. If elected, the Coalition Avenir Québec (CAQ) made a similar promise to pay $\$ 8$ billion in the first year and \$2 billion the following year. In both cases, the announcement was welcomed by some economists and financial analysts, but not by others.

In the Rapport préélectoral sur l'état des finances publiques du Québec (Pre-electoral Report on the State of Québec's Public Finances) published by the Ministère des Finances on August 20, 2018 , we read that the QLP plan would lead to an expected $\$ 1.1$ billion decrease in interest

\footnotetext{
${ }^{3}$ https://www.nytimes.com/2016/11/21/opinion/build-he-wont.html

${ }^{4}$ https://www.nytimes.com/2016/11/21/opinion/build-he-wont.html
} 
payments and $\$ 1.9$ billion in forgone investment income over five years. To simplify, let us assume that the same applies to the CAQ plan. We could conclude, as many have, that this is a bad idea financially: $\$ 1.1$ billion in interest savings at a cost of $\$ 1.9$ billion in lost investment income. Moreover, since the Generations Fund is already factored into calculation of the debt, this approach is actually the equivalent of taking $\$ 10$ billion from the right pocket and putting it into the left pocket.

Between 2007 and 2015, the Fund generated an average annual return of 5.67 per cent, with a low of -22.4 per cent in 2008, compared to an average annual cost of debt financing of 3.7 per cent. When the Fund was created in 2006, the Ministère des Finances du Québec calculated that over the period 1995-2005 the cost of financing the debt was 6.9 per cent, compared to the Caisse de dépôt et placement du Québec's overall rate of return of 9.4 per cent, hence the Fund's anticipated attractive profitability.

That comparison is flawed. As mentioned above, the former rate does not take into consideration the cost of the implicit financial insurance or option granted to the government by citizen taxpayers that underlies the government's low cost of financing. As to the second rate, it includes a non-negligible risk premium. The financial profitability of the Fund, once the risk borne by taxpayers is taken into account, is much less clear. Is it a good idea or a bad idea?

Contributions to the Fund have become politically unavoidable and inescapable, which is ultimately the most important positive element, perhaps even trumping the underestimation of the cost of the sums invested in the Fund. ${ }^{5}$ Voters would take a dim view of any government, whatever its brand, that did not contribute to this each year from its current budget. This "quasi-religious" requirement can be used to force the government to save and implicitly repay its debt, which it could more easily neglect to do otherwise. In this sense, the contributions have become inescapable, and the Fund's existence constrains the government to be more disciplined in its budget and indirectly repay its debt.

This approach to comparing the cost of financing the debt and the performance of the Generations Fund, managed by the Caisse de Dépôt et Placement du Québec, reflects a serious analytical error that is widespread within the government, private, and academic sectors. This error mirrors the error that governments have a significant advantage over private companies in financing a project because they can borrow at lower interest rates, and it is ubiquitous, recently appearing in the evaluation of Montreal's Réseau express métropolitain, or REM (automated light rail network) project ( $\$ 6$ billion) and the BC Hydro Site $C$ hydroelectric project

\footnotetext{
${ }^{5}$ See Boyer, Gravel, and Mokbel (2013) refered to in footnote 1.
} 
(\$11 billion). As noted above, the error lies in confusing the cost of government financing (interest on the debt) with the cost of public funds.

\section{THE REM}

The Réseau express métropolitain, or REM (automated light rail system), is an automated subway system connecting 26 stations over a range of $67 \mathrm{~km}$ between Montreal's downtown, airport, and greater metropolitan area. It is being built by CDPQ-Infra, the infrastructure subsidiary of the Caisse de dépôt et placement du Québec (Quebec Deposit and Investment Fund). Even though the Fund, and by extension CDPQ-Infra, are owned by the Government of Quebec, for purposes of the REM project is can be treated as a private partner, manager, and investor, since it is mainly accountable to its financiers-one of the main ones being the Government of Quebec.

In a recent article in La Presse, ${ }^{6}$ we learned that the Fund will capitalize on the experience acquired with the REM project to market skills in the design, delivery, management, and financing of similar light-rail endeavours around the world (beginning with Auckland, New Zealand).

According to its management, the REM project, and in particular the role played by CDPQ-Infra, is attracting a great deal of interest in the United States, Europe, the rest of Canada, and Oceania. The Auckland project, expected to cost several billion dollars, will be a first attempt to export the professional skills of CDPQ-Infra, not only as a financier, but also as an entrepreneur, designer, builder, and manager. In the United States alone, the infrastructure plan announced by President Trump is expected to invest 1000 billion US\$ over the course of a ten year period to restore America's infrastructure. The financing will mostly be from the private sector-which, for these purposes, includes CDPQ-Infra. ${ }^{7}$

Michael Sabia, CEO of the Fund, is quoted as follows in the article, "The world is ready for some new ideas, new ways to fund and envision infrastructure projects. Globally, there is an annual infrastructure deficit of at least $\$ 1000$ billion. All the experts understand that it will be impossible for governments to come up with the required funding."

The Fund's Financial information note March 2018) reads as follows: "Until CDPQ-Infra's priority yield reaches 8 per cent, dividends from the REM project will be earmarked exclusively for

\footnotetext{
${ }^{6}$ http://www.lapresse.ca/affaires/economie/transports/201807/30/01-5191257-rem-montreal-dabord-le-mondeensuite.php?utm categorieinterne=trafficdrivers\&utm contenuinterne=cyberpresse hotTopics 4244223 section POS1

${ }^{7}$ On this subject, see M. Boyer, "Le Plan Infrastructure de DJ Trump," CIRANO, September 12, 2017. https://www.youtube.com/watch?v=vfbrchBlOr8\&t=248s
} 
CDPQ-Infra. When this level of yield has been reached, most of the yield (72 per cent) will be paid out to minority shareholders (the governments of Quebec and Canada) up to the minimum return provided for in the contract (3.7 per cent). This 3.7 per cent is equivalent to the Government of Quebec's average borrowing cost on its overall debt ... When all shareholders have received the level of yield provided for by the contract, dividends will be paid out in proportion to each one's participation, i.e. 51 per cent to CDPQ-Infra and 24.5 per cent for the two levels of government" (author's translation). This Note predates the Federal Government's change of status from shareholder to lender (Infrastructure Bank), but this does not materially affect our conclusions here.

How does this formula fleece tax payers? As we saw above, the financing cost of the Government of Quebec's debt (3.7 per cent) does not reflect the burden on taxpayers of the cost of government borrowing. These taxpayers are being ripped off by the Fund and the Government, not because of any intent to deceive, but rather because of a profound failure to understand why the Government's borrowing cost is 3.7 per cent. This error corresponds to the first misunderstanding that I analyze in the previously cited article. ${ }^{8}$ There must also be an account of the additional and non-negligible risk the governments assume in light of their second-tier position with regard to the Fund's dividend payment scheme.

Formulated by the Caisse with the approval of the Government, this major methodological error does not necessarily detract from the legitimacy of the REM project. Nevertheless, the error is in no way negligeable.

Thus, in the case of REM we see that the government is wearing two hats: that of financier / investor, or shareholder, in REM ( 2 times 24.5 per cent of the capital) on taxpayers' behalf, and that of beneficiary (or "buyer") of the REM's services on citizens' behalf.

In its first role, the Government must ensure that the interests of taxpayers, who guarantee (or insure) its debt, are adequately represented and compensated by a return to investment that reflects the risk incurred. The return to the Government's investment should be more like 9 or 10 per cent, rather than 3.7 per cent, in light of the fact that depositors in the Fund, who assume the same risk, receive a yield of (8 per cent), and also in consideration of the Government's secondary position in the distribution of dividends (+1 or 2 per cent).

Of course, in its role as beneficiary or buyer of the services provided by REM on behalf of citizens, the Government may wish to subsidize its construction in order to efficiently provide a

\footnotetext{
${ }^{8}$ Marcel Boyer, "Erreurs méthodologiques dans l'évaluation des projets d'investissement." Revue Française d'Économie XXXIII (2018/4), April 2019, 49-80 https://www.cairn.info/revue-francaise-d-economie-2018-4-page49.htm . Also see Marcel Boyer, Éric Gravel, and Sandy Mokbel (2013) refered to in footnote 1.
} 
boost to ridership. From this perspective, even if the distribution of dividends is formally improper, this mistake may very well not reverse the validity of the REM project.

Nevertheless, the Government's two roles are different and should be analyzed separately and correctly, if only for transparency in the use of public moneys.

\section{INFRASTRUCTURE ONTARIO'S ASSESSMENT OF THE RISKINESS OF COSTS}

The Infrastructure Ontario website states:" "Infrastructure Ontario (IO) is a Crown agency of the Province of Ontario that supports the Ontario government's initiatives to modernize and maximize the value of public infrastructure and real estate. 10 upholds the government's commitment to renew public services and we often do so in co-operation with the private sector. At IO, we think of ourselves as a private sector company doing public service. This philosophy has created a culture of people leveraging best practices from the world of business to protect and advance the public interest. We believe in the potential of the public and private sector working together. All IO business lines have a track record of building successful relationships with the private sector to benefit Ontarians across the province."

The approach used by Infrastructure Ontario (IO) to assess and compare the cost of a project undertaken by the public sector with the cost of the same project undertaken by the private sector is in some ways fundamentally flawed. Contrary to their claims, IO's methodological approach systematically incorporates several errors and is therefore likely to result in significant losses in economic value to taxpayers.

According to the methodological guide (2015) prepared for Infrastructure Ontario by Deloitte, ${ }^{10}$ "As the public sector financing rate reflects the virtually unlimited taxing power of the crown to repay its debts, crown borrowings are viewed as being risk-free. Since crown borrowings are viewed as risk-free, the appropriate rate to use for discounting project costs is the public sector financing rate." As we will see below in the section on BC Hydro Site C hydroelectric project, the same error appears to have been embraced by KPMG.

As demonstrated above, the cost of public sector borrowing hides another cost, namely that of the insurance policy or financial option implicitly granted by taxpayers to their government to raise additional funds (taxes), if necessary, to compensate and reimburse lenders.

\footnotetext{
${ }^{9}$ https://www.infrastructureontario.ca/About-Infrastructure-Ontario/.

${ }^{10}$ Infrastructure Ontario (Deloitte LLP), Assessing Value for Money, An Updated Guide to Infrastructure Ontario's Methodology, Queen's Printer for Ontario, March 2015.
} 
As a result, the valuation methodology followed by 10 will generally lead to erroneous and potentially value-destroying decisions because the cost of public funds is systematically undervalued. The IO-Deloitte approach invokes the government's power of taxation to justify a risk-free discount rate, since government borrowing is considered risk-free. These loans may be considered risk-free by lenders, but certainly not by the taxpayers who have to foot the bill if public projects turn out to be less profitable than expected. We demonstrated above that using the risk-free lending rate as the discount rate for public projects is a major error in evaluating public projects.

The Guide also states that the discount rate used should reflect the uncertainty inherent in cash flows and that, on that basis, a case could be made for discounting costs at a higher rate (a riskfree rate plus a risk premium) if there is greater risk in the costs. However, again according to IO-Deloitte, this would lead to the counterintuitive result that a project would be less costly in discounted dollars the riskier and therefore more highly discounted its future costs. According to IO, one good way to avoid this result is to quantify the risks through a comprehensive risk assessment and to increase the estimated project costs by the value of these risks. At Infrastructure Ontario (2015, p. 25), we read:

"Discounting hinges on the rate used to estimate the value of a future dollar in today's terms. Since the project costs are in future dollars, and are estimated costs that may turn out to be different (e.g. higher) than projected, the discount rate chosen should match the uncertainty inherent in these cash flows. Since higher risks require higher returns, one could argue for a higher discount rate (i.e. risk-free rate plus risk premium) to capture the uncertainty in the project costs. However, this leads to the counterintuitive result of future uncertain costs being heavily discounted leading to a project appearing less costly in present-day dollars as a result of this increased risk. An appropriate method to avoid this result is to quantify the embedded uncertainty in costs through a comprehensive risk assessment. The quantified risks (i.e. cost of risk) can be added to the estimated project costs resulting in virtually 'risk-free' costs. This 'riskfree' cash flow stream can then be discounted back and expressed in dollars as at bid submission date at a 'risk-free' rate. As the public sector financing rate reflects the virtually unlimited taxing power of the crown to repay its debts, crown borrowings are viewed as being risk-free. Since crown borrowings are viewed as risk-free, the appropriate rate to use for discounting project costs is the public sector financing rate. Infrastructure Ontario has chosen to be conservative and transparent by accounting for 
risks exclusively through risk quantification workshops, rather than adding a risk premium to the discount rate."

IO-Deloitte claims that it wants to be conservative and transparent. This procedure may be conservative and transparent, but it is wrong and will generally lead to wrong decisions.

It may be counterintuitive that a project whose future costs are riskier-their present value thus being lower-would have a higher present value, but this result is nevertheless correct, provided that the level of systematic risk of the cost is properly measured. Indeed, if costs are systematically riskier, they will be higher when market returns are high and lower when market returns are low. This increases the value of the project and should not lead to arbitrary manipulations ("comprehensive risk assessment" in IO jargon) in order to "avoid this result," which is considered paradoxical. This is an incorrect use of NPV and its certain equivalent version. Moreover, there seems to be confusion here between real risks and financial risks. ${ }^{11}$

A third methodological shortcoming in the 10 approach is to apply the same (risk-free) discount rate to all public sector projects irrespective of individual projects' specific risk profiles. Using a single discount rate could lead to the destruction of value, since some (or even most) projects are exposed to risk from several sources. Thus, some profitable projects will be rejected and some unprofitable ones accepted. In the presence of multiple and different sources of risk, the usual NPV methodology used by 10 is inconsistent with the principles of both additivity and the absence of arbitrage, which are the very foundations of modern finance. In order to avoid this error, the Optimized Net Peresent Value (O-NPV) should be used. ${ }^{12}$

\section{BC HYDRO SITE C HYDROELECTRIC MEGAPROJECT}

BC Hydro's Site C Clean Energy Project will be a third dam and hydroelectric generating station on the Peace River in northeast B.C. ${ }^{13}$ It will provide 1,100 megawatts (MW) of capacity, and produce about 5,100 gigawatt hours (GWh) of electricity each year. Construction of the project started in summer 2015. The generators will be on line in 2024 and the project will be completed in 2025 . The cost of the project is estimated at over $\$ 10$ billion.

The Clean Energy Association of British Columbia (CEABC) challenges specific aspects of the British Columbia Utilities Commission's (BCUC) Preliminary Report dated September 20, 2017

\footnotetext{
${ }^{11}$ On this subject, see Marcel Boyer, Martin Boyer and René Garcia (2013), "Alleviating Coordination Problems and Regulatory Constraints through Financial Risk Management," Quarterly Journal of Finance 3(2), 39 pages.

12 See Marcel Boyer and Éric Gravel (2006), "Évaluation de projets : La valeur actualisée nette optimisée (VAN-O)," Insurance and Risk Management, 74(2), July 17, 2006, 163-185.

${ }^{13}$ https://www.sitecproject.com/about-site-c/project-overview
} 
regarding the Site $C$ review. More specifically, it identified, among others, the following financial issues as relevant to the evaluation of the Site $C$ project: ${ }^{14}$

A. The use of $100 \%$ debt financing for a public project.

B. The use of a 70-year amortization period to calculate the Unit Energy Cost (UEC) and the extent of the potential interest rate risk this can have on Site C's economics.

C. The use of different discount rates when comparing mutually exclusive projects.

The main results of my analysis were as follows.

With the current Site $C$ financial model there is, in effect, no (or zero) equity that requires a return. BC Hydro's financial analysis of Site $\mathrm{C}$ makes a major error in assuming that ratepayers and taxpayers need not be compensated for bearing project risk, and the low unit energy cost follows from a significant downward biased miscalculation of the effective or real costs of the project. ${ }^{15}$

This error opens the door to significant distortions in investment evaluation, especially when comparing the alternative options, with potentially hundreds of millions of dollars, even billions of dollars of value at stake of being destroyed through a misleading evaluation methodology. The remedy to this error is the application of a proper risk premium either in the form of a large portion of equity and risk adjusted equity return or a larger contingency, or a combination of both. There are industry examples of utility-water projects with debt equity ratios of $43 \%$ (i.e. $30 \%$ debt/70\% equity). However, given the equity risk, size, complexity and longevity of a nonrecourse project like Site $C$, the $B C$ Government should require $B C$ hydro to evaluate Site $C$ on the basis of at least $40 \%$ equity.

BC Hydro used an $11.84 \%$ return on equity for all projects except for Site C. The Provincial Government allowed BC Hydro to do that by announcing a new policy just before they approved

\footnotetext{
${ }^{14}$ I was asked by the CEABC to comment on those issues. See https://www.bcuc.com/Documents/wpcontent/10/00589 F18-5 CleanEnergyAssociationofBC SiteC Submissions-1.pdf (Appendix 1). The final report of the B.C. Utilities Commission dated November 12017 is available here: https://www.bcuc.com/Documents/wpcontent/11/11-01-2017-BCUC-Site-C-Inquiry-Final-Report.pdf. The Commission referred to my Report on pages 146-148.

${ }^{15}$ BC Hydro states (https://www.sitecproject.com/sites/default/files/site-c-business-case-2014.pdf, page 23) that an external peer review by KPMG determined that both the process for developing the assumptions and the construction of the financial model used in the cost estimate were appropriate (see https://www.sitecproject.com/sites/default/files/2011-05-09-KPMG\%20Commentary\%20Letter.pdf).
} 
Site $C .{ }^{16}$ The Government should require BC Hydro to use at least $11.84 \%$ return for the equity investment in Site $\mathrm{C}$.

Seventy years is a very long term for Site C or any project's financial analysis. Combining that very long investment term with important risks from diverse factors such as market demand risks, technological innovation risks, stranded assets risks, climate change risks, and political risks (exportation) necessitates a rate of return for Site $C$ between $10 \%$ to $13 \%$ (and possibly higher).

The best way to protect ratepayers from rate increases is to consistently make the right investment and operation decisions. Unfortunately, too many public utilities suffer from the same disease as too many government organizations: they turn out to be political entities with an aversion to rigorous financial principles. The way to achieve an optimal investment portfolio is to follow evaluation methodologies that are rooted in sound economics and finance and to apply them as rigorously as possible. One thing is sure: hiding costs by transferring risks to taxpayers without proper compensation one way or another is not the way to do it.

\section{A. The use of $100 \%$ debt financing.}

The use of debt and equity (there may be many classes of debt and equity, an aspect that I will not address here) in a private firm is basically to save on taxes, as interest on debt is generally deductible from taxable income, as well as to take advantage of the lower cost generally associated with the use of debt, from the design of a two class financial structure with higher priority given to debt holders. Insofar as BC Hydro is not taxable, the first reason plays a very limited role in the present context. Moreover, since BC Hydro debt is totally guaranteed by the Government one way or another, the discussion here must be read as applying to a private firm. Later I will discuss the case of BC Hydro as a Crown corporation.

In private firms, the debt/equity $(D / E)$ ratio is used to create two classes of financiers in the project with different priorities as far as compensating payments are concerned. But the inherent project risk is otherwise independent of the $D / E$ ratio. In a sense, there are three different cash flows, and each is subject to its own risks. Some of the risks are determined by the projects inherent risks, and some of the risks are a function of the financial contracting between the financing parties.

\footnotetext{
${ }^{16}$ In November 2014 the B.C. government announced the 10 Year Rate Plan which allowed BC Hydro to waive the traditional Return on Equity calculation and the Dividend calculation for its major Site $C$ hydroelectric project, as well as set rate increases of $15 \%$ over the ensuing 2 years. It enabled BC Hydro to artificially and significantly reduce Site C's unit energy cost (UEC) and to state that Site C's UEC appears to be much lower than the UEC for the Alternative Clean Energy Block project. In December 2014 the provincial cabinet approved the Site C project.
} 
However, this split in the project financing structure between debt and equity is basically a way, a potentially profitable way, to allocate the project's risk between the two groups of financiers who may have different aversion to risk taking. Debt holders have priority over equity holders if available funds are insufficient to adequately compensate both groups. In exchange for this priority, debt holders are entitled to fixed repayment schedules and conditions, while the equity holders are residual claimants and payees and will receive whatever is left after the debt holders are paid. For this reason, debt holders will require a lower return (interest rate) on their investment in the project as their investment in the project is less risky and equity holders a higher return as their investment in the project is riskier. Equity holders face two factors of risk, one from the uncertain cash flows of the project (which affects also debt holders) and one from their lower priority to those cash flows.

Therefore, a $100 \%$ debt financing of an investment project in a private firm is akin to a $100 \%$ equity financing of the same project, with the same financing cost in both cases. In the case of a public firm, the situation is more complex because the debt is nonetheless shielded from risk by the presence of "hidden equity" in the form of ratepayer and taxpayer guarantees. This "hidden equity" is equity bearing all the residual risk, but it has zero investment and zero return. In the case of Site C, however, I understand that it is not really $100 \%$ debt financed. It is only $60 \%$ debt with the $40 \%$ of the funds that are put up by the Government/taxpayers are assumed to receive a zero rate of return.

If the risk-free rate is $4 \%$ and the risk premium is $6 \%$, then an investment with an unlevered beta of 1 (that is, similar to the overall or broad market risk) would require a rate of return of $10 \%$. If the unlevered beta is 1.5 (50\% more risky than an investment in a broad market index), then the required rate of return would jump to $13 \%$.

For a very long term investment such as BC Hydro's Site $\mathrm{C}$ project, a required rate of return and discount rate of between $10 \%$ and $13 \%$ (and possibly more) would be warranted given the important risks involved coming from diverse factors, among which the following are nonnegligible: market demand risks, technological innovation risks, stranded assets risks, climate change risks, and political risks (exportation).

There are no simple methodologies to estimate and quantify those risks. Two main methodologies can be used: First, simulation studies based on relevant stochastic processes capturing the essential elements of uncertainty as parameters of trend and volatility, where the parameters of interest are varied in sensitivity analyses. Second, the identification of the market risk attached to the traded stock of firms whose portfolio of assets matches as closely as possible the characteristics of BC Hydro Site $\mathrm{C}$, in particular their very long term amortization period. But it would be challenging for obvious reasons to find such firms. Both methodologies 
are complex and challenging but nevertheless possible and necessary. The first methodology seems more promising. ${ }^{17}$

In a Crown corporation like BC Hydro, for which all debt is fully backed by the Government, the distinction between debt and equity is rather blurred. Actually, the ratepayers are acting as the first line of equity holders. They are the first line of defence that protects the debt holders from any project cost overruns, schedule delays, future interest rate increases, or underperformance risks of all kinds (including operating, maintenance, and capital replacement costs, and even climate change or water supply, as well as technological and stranded asset risks). The ratepayers are the first recourse if the project does not meet its expectations in any way.

After the first recourse to the ratepayers, the second recourse is to taxpayers through the intervention of the Government if it looks like the burden on the ratepayers might exceed a politically acceptable level. The ratepayers and taxpayers are then supporting the total risk of the project, not the lenders or debt holders. In other words, ratepayers and taxpayers are holding a significant level of "hidden equity" for which they are not compensated.

Properly defending the interests of ratepayers and taxpayers, which is arguably the major role of Governments, requires that the risk or risks of the project be correctly evaluated and priced into the project. The standard methodology used for the evaluation of public projects suffers from serious flaws, particularly with respect to the use of a discount rate corresponding to the government's cost of financing.

My analysis suggests that the underlying rationale for the approach $\mathrm{BC}$ Hydro and the $\mathrm{BC}$ Government appear to adopt stems from the analytical illusion that the cost of capital incurred by the private sector to undertake a project is higher than the cost of capital incurred by the public sector to undertake the same project (same characteristics, same real risks, same financial risks).

This analytical illusion is due to the fact that a significant portion of the government's cost of capital is not recognized and not accounted for, namely the implicit option granted by taxpayers to their government to require additional funds in order to meet the commitments made to the lenders if and when a project does not meet the expected level of profitability. Discounting at an essentially quasi risk-free rate is often rationalized by "the virtually unlimited taxing power of

\footnotetext{
17 See Boyer, M., et alii, Méthodes avancées d'évaluation d'investissement / Advanced Methods of Investment Evaluation, Monographie CIRANO Monograph (2 tomes / volumes), Hiver/Winter 2017, 601 pages, in particular chap.8 Fundamentals of Real Options Valuation; chap.12 Identifying, Creating and Managing Real Options; chap.15 Application de la théorie d'options réelles pour l'évaluation économique d'une interconnexion entre deux marchés d'électricité; chap.18 Prise en compte de la volatilité dans les questions de valorisation long terme des actifs physiques. http://cirano.qc.ca/files/publications/2017MO-03.pdf (Tome 1) and http://cirano.qc.ca/files/publications/2017MO-04.pdf (Tome 2)
} 
the Crown": the project may appear quasi risk-free to lenders, but is obviously not risk-free for ratepaying and taxpaying citizens.

If the Government has no interest other than that of the citizens it represents, the allocation of public funds to investments should follow the same principles used in the allocation of private funds. Although the government does not usually relate its borrowing to the funding of specific projects, it remains true that regardless of the project, investment, loan or subsidy, the implicit guarantee taxpayers grant the government allows it to offer the lenders an essentially risk-free deal. Taxpayers do not get the same deal.

For a private firm, the lower the share of a project financed by debt through a lower D/E ratio, the lower the project risk supported or incurred by debt holders will be, the higher the rating of the debt will be, the lower the interest rate required by lenders will be.

Conversely, the larger the share of a project financed by equity through a lower D/E ratio, the lower the (given) project risk supported or incurred by equity holders will be, as those equity holders are better protected (have a higher priority on the cash flows of the project), the lower the return required by equity holders will be.

Similarly, as the D/E ratio increases from $50 \%$ to $100 \%$ to $200 \%$, the higher the share of the project financed by debt is, and the riskier the debt becomes, translating into a higher interest rate required by lenders.

The important lesson one must keep in mind is that, for private firms, debt and equity are communicating vessels. In fine, if a private firm project is financed $100 \%$ by debt, there is "no debt" in the usual sense as there are no other residual claimants than lenders and the debt holders support $100 \%$ of the risk of the project. Debt becomes equity. More precisely, debt is assuming the role of equity, unless those debt holders are contractually protected by some form of guarantee from a credit-worthy party, like a parent corporation, or even an implicit guarantee from the customers (i.e. that they agree to pay higher prices to protect the debt holders from any loss).

If $\mathrm{BC}$ Hydro were a private firm, $\mathrm{BC}$ Hydro would appear to be making the error of assuming that a $100 \%$ debt-financed project could benefit from a constant and low cost of debt, guaranteed by the government acting as a "parent corporation". Since, as I discussed above, the cost of debt is commensurate to the risk supported by the lenders, the higher the D/E ratio, the riskier the debt becomes and the higher the interest rate on the debt will be. If the financing of the project is $100 \%$ debt, then debt support $100 \%$ of the project risk; and similarly, if the financing of the project is $100 \%$ equity, then equity supports $100 \%$ of the project risk. In both case, the required return is the same, whether it takes the form of or is called interest on debt or return on equity. 
Given that BC Hydro is a Crown corporation whose debt is totally guaranteed by the $B C$ Government, the debt holders are not supporting the BC Hydro project risk even if the project appears to be financed $100 \%$ by debt. The reason is that the project risk is being transferred to ratepayers and taxpayers, acting collectively as a virtual "parent company".

The way by which Site $C$ is being evaluated by $B C$ Hydro and the BC Government assumes that ratepayers and taxpayers need not be compensated for bearing the project risk. This error opens the door to significant distortions.

The only sensible way to evaluate such public sector investments without making the major error mentioned above is to include in the cost of public projects, such as BC Hydro's Site C project, a proper compensation of the risk supported by ratepayers and taxpayers. It could be done through different channels: by assuming a proper risk premium on the financing charge, by explicitly including a large portion of "equity" and a "risk adjusted equity return", by adding more and larger contingency allowances, or by some combination of these as well as some other equivalent measures.

The statement by PRWMFN (Prophet River and West Moberly First Nations) to the effect that "[w]ithout a requirement to provide any financial return - because there is no equity with which to provide a return - the unit energy cost can be decreased, but this is the equivalent of a mirage" is completely in line with this result. It is indeed a "mirage", as the lower unit energy cost follows from a significant downward biased miscalculation of the effective or real costs of the project as an important share of the risk of the project; the share supported by ratepayers and taxpayers, is hidden and not compensated.

Observed D/E ratios across firms and industries. There is no uniquely or simplistically determined $D / E$ ratio for a given firm or a given industry. The ratio affects incentives for exerting efforts (moral hazard) in managing risks and for putting more competent managers (adverse selection) on risk management tasks. Equity holders will in general be more sensitive to and interested in risk management than debt holders given their lower priority in the distribution of cash flows generated by the project or the firm. The ratio affects also the rating of the firm's debt by rating agencies. Indeed, riskier projects usually require more equity, and more equity allows a better rating of debt by rating agencies, hence a lower interest on debt.

We observe relatively low industry wide D/E ratios in Oil/Gas-Integrated (17\%, that is, $85 \%$ equity financed and $15 \%$ debt financed), Aerospace and Defense ( $24 \%$, that is, $81 \%$ equity financed and $19 \%$ debt financed), Building Materials (27\%, that is, $79 \%$ equity financed and $21 \%$ debt financed), Transportation Railroads (28\%, that is, $78 \%$ equity financed and $22 \%$ debt financed), Engineering/Construction (32\%, that is, $76 \%$ equity financed and $24 \%$ debt financed). 
We observe relatively high D/E ratios in Coal and related Energy (139\%, that is, $42 \%$ equity financed and $58 \%$ debt financed), Green and Renewable Energy (174\%, that is, $36 \%$ equity financed and $64 \%$ debt financed), Power ( $87 \%$, that is, $53 \%$ equity financed and $47 \%$ debt financed). For wind power projects, D/E ratio may reach $230 \%$ or more: "relatively high gearing in wind projects of about $50 \%-70 \%$ debt financing, where onshore and offshore projects are typically in the upper and lower range, respectively. The difference is due to the larger risk in offshore projects." 18

And we observe relatively in-between or medium level D/E ratios in Oil/Gas-Production and Exploration (47\%, that is, $68 \%$ equity financed and $32 \%$ debt financed), and Utility-Water (43\%, that is, $70 \%$ equity financed and $30 \%$ debt financed). ${ }^{19}$

I understand that the BC Government has determined that $40 \%$ is the amount of "equity" it considers appropriate to put into BC Hydro. I put equity in quotation mark because it is not exactly the same as equity in a private project. Since, as I argued above, the riskiness of a project is independent of the owner of the project, that is, whether that owner is public or private, the financial analysis of the project can be done "as if" it was privately run at least as far as the evaluation of costs is concerned.

That would give a Debt to Equity ratio of $150 \%$, reasonably in line with industry. One possibility to cut the Gordian knot of Site C project evaluation is to hold BC Government responsible for inducing that proportion in the evaluation of Site $\mathrm{C}$, that is, to require $\mathrm{BC}$ Hydro to actually evaluate the Site $C$ project on that basis, with the proper cost of debt and equity, rather than pretend to benefit from a $100 \%$ debt mode.

I understand that BC Utilities Commission determined an appropriate equity rate of return for BC Hydro to be $11.84 \%$, which should be used for all general project evaluations, that is, for all projects that mimic the overall risk or the average risk of the corporation (see also my second comment in section C below regarding the WACC fallacy). The Government should require BC Hydro to use no less than this $11.84 \%$ for its investments, although for such a large, complex and long lasting project as Site $\mathrm{C}$, there should be an additional premium on top of that basic equity rate of return to take into account the additional risks that are somewhat outside the range of BC Hydro's normal business.

\footnotetext{
18 Deloitte, Establishing the investment case - Wind power, 2014. Note that a D/E ratio above $230 \%$ means more than $70 \%$ debt financing and less than 30\% equity financing for lower risk onshore wind power projects, while a D/E ratio of $100 \%$ means $50 \%$ debt financing and $50 \%$ equity financing for higher risk offshore wind power projects.

${ }^{19}$ Aswath Damodaran, New York University Stern School of Business. http://www.damodaran.com
} 
For the rate of interest on the Debt portion, it should be what institutional lenders would require in the private sector for a stand-alone, non-recourse project of the same size, complexity, and longevity as Site $C$ with a $40 \%$ equity investment.

The following table illustrates the implications of the above discussion. The last line represents realistic financial parameters for Site C. I put "WACC" in quotation marks to indicate that the concept is not directly applicable to a public sector project. However, given the discussion above, it is a reasonable compromise for the cost of capital of $B C$ Hydro in Site $\mathrm{C}$ project.

\begin{tabular}{|c|c|c|c|c|}
\hline Debt rate & Debt financed & Equity rate & Equity financed & "WACC" \\
\hline$\%$ & $60 \%$ & $0 \%$ & $40 \%$ & $1.80 \%$ \\
\hline $3 \%$ & $70 \%$ & $0 \%$ & $30 \%$ & $2.10 \%$ \\
\hline $3.43 \%$ & $100 \%$ & $11.84 \%$ & $0 \%$ & $3.43 \%$ \\
\hline $3 \%$ & $70 \%$ & $11.84 \%$ & $30 \%$ & $5.65 \%$ \\
\hline $4 \%$ & $70 \%$ & $11.84 \%$ & $30 \%$ & $6.35 \%$ \\
\hline $3 \%$ & $60 \%$ & $11.84 \%$ & $40 \%$ & $6.54 \%$ \\
\hline $4 \%$ & $60 \%$ & $11.84 \%$ & $40 \%$ & $7.14 \%$ \\
\hline $6 \%$ & $60 \%$ & $11.84 \%$ & $40 \%$ & $8.34 \%$ \\
\hline $\mathbf{6 \%}$ & $\mathbf{6 0 \%}$ & $\mathbf{1 3} \%$ & $\mathbf{4 0 \%}$ & $\mathbf{8 . 8 0} \%$ \\
\hline
\end{tabular}

B. The use of a 70-year amortization period

It often appears better to model with an appropriate stochastic process (subject to sensitivity analysis) the residual value of the equipment/project at year thirty or forty than to try to forecast all relevant variables for a period of over 70 years. A proper comparison of mutually exclusive projects requires that projects (and their replications) must span the same period. The usual way to do this is by replicating projects (replacement chain) up to the point where all projects have the same or similar reference period. Hence if two mutually exclusive projects are considered, with reference periods of respectively 70 years (project 1 ) and 35 years (project 2), the proper way to compare those projects is to consider the 70-year project 1 and two consecutive 35 -year projects 2 , each option being properly discounted at their respective discount rate.

It may be useful to note here that the European Commission recommends the following maximal reference periods for long term projects: 
European Commission's reference periods by sector

\begin{tabular}{l|c}
\multicolumn{1}{c|}{ Sector } & Reference period (years) \\
\hline Railways & 30 \\
Roads & $25-30$ \\
Ports and airports & 25 \\
Urban transport & $25-30$ \\
Water supply/sanitation & 30 \\
Waste management & $25-30$ \\
Energy & $15-25$ \\
Research and Innovation & $15-25$ \\
Infrastructure & $10-15$ \\
Other sectors & $10-15$
\end{tabular}

The challenge here is to forecast at what conditions the replication of the second project will be made in 35 years and what portion of it will need replacing (not all elements of the 35-year project or equipment would need to be replaced in 35 years, thereby reducing the present value cost of the second option). It may be the case that, due to technological development and innovation, the investment cost required, in real dollar terms, will be significantly lower than the year 0 investment.

A proper stochastic model (subject to sensitivity analysis) of innovation can and should be developed to ascertain the expected reinvestment level necessary for a replacement project, 35 -year from now. The additional flexibility the investor has in considering two 35 year projects (regarding the time to reinvest and whether reinvestment is warranted or not and at which financial and technological conditions) versus one 70-year project has a real option value. In real option valuation (ROV) analysis versus net present value analysis (NPV), the possibility to abandon the reinvestment project (not reinvesting) in 35 years has value and makes more valuable the two 35 year projects option. This value appears to be explicitly ignored by BC Hydro in its comparative evaluation of the Alternatives.

Finally, the significant uncertainty involved in the evaluation of very long term projects favors the explicit use of properly calibrated stochastic real option models in order to reduce the level of arbitrariness in the estimation of costs and benefits, in particular the end or terminal value of the equipment/project. This can and should be done. ${ }^{20}$

\footnotetext{
${ }^{20}$ See footnote 18 above.
} 


\section{The appropriate discount rates}

My discussion here parallels the discussion presented in the introduction. For the sake of providing a reasonably integrated analysis of $\mathrm{BC}$ Hydro Site $\mathrm{C}$ project, some elements are repeated here.

My first comment relates to the "commonly held" view and often repeated statement that the private sector is in a good position to manage project costs and meet deadlines, but not, generally, to fund or finance projects. The underlying argument runs as follows: because the interest rate on government borrowings (the government's debt financing cost) is lower than that of the private sector, the cost of goods or services will necessarily be lower if the project is funded by government. However, such an argument builds on the confusion between the cost of financing and the cost of capital (or discount rate). The analytical error resides in the assessment of the true cost of public funds. This is a subtle but important error that is widespread in both the public and private sectors as well as in academia.

It is undeniable that the public sector can generally borrow at lower interest rates than the private sector to finance a given project. But this begs the question: Why? Why is the cost of financing lower for a public sector enterprise if that enterprise is involved in the same project or activities and in the same way as a private sector company - same technology, same inputs, same markets, same prices - and therefore faces the same risk factors?

The answer is that a government has the power to levy additional fees and taxes to compensate and repay its lenders if the project incurs cost overruns and/or generates lower than expected benefits. The interest rate paid by the public sector reflects the fact that, through its taxation power, it implicitly subscribes a loan insurance wherein taxpayers act as the insurer. This means that lenders to the public sector will require at most a relatively small risk premium regardless of the risk of the project because those lenders are not subject to the risk of the project. This is clearly not the case for the private borrower who does not have such taxation power.

The risk premium normally required by the lender will depend on several factors: the probability of default, the estimated loss in case of default and an assessment of the systematic (nondiversifiable) risk associated with these two quantities. A lender is not directly interested in the borrower's identity (public versus private) when determining the risk premium, the only important factors being the probability of default and the loss to be incurred in case of default (both the probability and loss being more generally expressed as distributions of probabilities and loss levels).

The lender will, however, show an indirect interest in the public sponsor if the latter provides a complete risk insurance borne by taxpayers, since this has the effect of reducing to zero the loss 
in case of default, thereby implying a zero or much reduced risk premium. As such, if a project fails, the public sector can repay the loan by increasing taxes or by reducing the number and/or quality of public services - in effect requiring compensation from the insurer (i.e., the taxpayers).

For the tax-paying public, the right and power of the state to demand additional contributions as required comes with a cost. This cost is real, but generally not acknowledged and not considered in the evaluation. It corresponds to the value of the financial option (or the insurance policy) granted by taxpayers to their government to obtain from them additional funds to cover a project's possible non-profitability ex post. The lower cost of funding is mainly due to the unaccounted implicit cost of this option or insurance policy held by a government.

If citizens gave a private company a similar option, i.e., the right to levy a tax if it was in financial distress, the private company could finance its activities at a rate similar to that of a government, public enterprise, or governmental agency.

All lenders require a premium related to the risk of default and associated potential loss. If the risk is borne by an insurer, represented here by the taxpayers, then the taxpayers as insurer should demand an equivalent risk premium: for a public project proponent, the requirement of a risk premium by the lender or its insurer (the taxpayers) must be taken into account. The proponent must then evaluate the project, taking into account the risk premium in order to avoid unduly depriving taxpayers of their due return or spoiling their interests.

In the investment community, there is much confusion between the risk ultimately borne by taxpayers and the cost of government funding which, reflecting the point of view of lenders, does not take into account the cost of the implicit insurance provided by taxpayers to their government. This translates into an error which is surreptitious and hidden, but which is nonetheless undeniable and may be extremely dramatic in its consequences.

This means that the cost of capital, which is a function of the project risk and which determines the discount rate, should fundamentally be the same whether a given project is public or private. The difference between the public and private sectors rests on their relative blend of competencies and incentives during both the construction phase and the operation phase of the project. This doesn't mean that Site $C$ should be evaluated using the same discount rate assumption as a much smaller, shorter-term, and less complex project, like a wind, solar, or small hydro project.

Each similar project should be evaluated the same way with the same cost of capital whether it is a public one or a private one. But two highly dissimilar projects, such as Site $\mathrm{C}$ and a much smaller, shorter term and less complex project, will be subject to different financing conditions 
and therefore different costs of capital. It is not whether the projects are private or public that matters, but rather the risk characteristics of the projects.

If BC Hydro's cost of debt referred to in BC Hydro statement "the cost to the ratepayer of financing Site C is equal to Hydro's cost of debt" (see BC Utilities Commission Preliminary Report subsection 6.3.1.2) is the firm-wide cost of debt financing of $\mathrm{BC}$ Hydro, then relatively riskier projects in BC Hydro portfolio of potential and actual projects will be overvalued, while the other projects, relatively less risky ones, will be undervalued.

If BC Hydro's cost of debt referred to in the BC Hydro statement is the BC government-backed cost of debt financing of $\mathrm{BC}$ Hydro, then the problem is even worse and the portfolio of projects undertaken will be even more biased towards riskier projects with a more important divergence between the actual portfolio of projects selected, and the optimal portfolio of projects.

BC Hydro is clearly committing this error when it writes: "For purposes of comparing BC Hydro and IPP projects, there should be recognition that BC Hydro will have a lower cost of capital given its access to the Province's high credit rating." 21

This will result in a suboptimal portfolio of actual projects and potentially significant losses of value for BC: billions of dollars are at stake of being wasted.

In summary, the argument that government funding is less expensive than private funding is not only wrong but also, unfortunately, ubiquitous in debates on public investments, especially for large infrastructure projects. This error is directly related to the determination of the appropriate discount rate for the evaluation of public investments, specifically how the risk of a public project is taken into account in cash flow stream discounting.

My second comment relates to the second mistake mentioned above regarding the proper use of the weighted average cost of capital (WACC), which averages the cost of debt and the cost of equity, each weighted by its importance in the capital structure of the firm/project. This is one of the three additional important mistakes identified in the C.D. Howe Institute Commentary \#388 mentioned above, which are all just as damaging as the one discussed in my first comment.

The phenomenon described in the BC Hydro use of WACC and its firm-wide cost of financing, whether based on BC Hydro cost of debt or BC Government cost of debt, has a parallel with respect to large corporations, but to a somewhat lesser extent. When private firms borrow against their corporate balance sheets, and all their diverse sources of income, rather than

${ }^{21}$ DOC_90351_F1-5_BC Hydro Site-C-Submission, IR 2.50.2 
against a single, perhaps risky project, the lender is not lending to the project specifically, but rather to the corporate entity, with all of its capabilities to pay back the loan, even if the project considered turns out to fail. Accordingly, the debt holder has access to many more assets, and revenue streams, than merely the one project.

Similarly, when BC Hydro or the BC Government borrow against all their diverse sources of income, rather than against a single, perhaps risky project, the lender is not lending to the project specifically, but rather to the government entity, with all of its capabilities to pay back the loan (include raising taxes, or electricity rates) or cutting on other government services. Accordingly, the debt holder has access to many more assets, and revenue streams, than merely the one project.

However, there is a fallacy in that reasoning, both for public sector and private sector investment evaluations. When using the company's cost of capital as a whole (WACC) in the assessment of its investments, one will overvalue and overinvest in some projects whose level of risk is higher than the average level of risk of the company's project portfolio. Similarly, one will undervalue and underinvest in other projects whose risk level is lower than the average risk of the company's project portfolio. Ultimately, this leads to a suboptimal portfolio of project investments and can cause a potentially large destruction of value in the company.

When assessing a particular project over another project, one must use a discount rate or cost of capital specific to those projects, pegging it to the project's systematic risk level. The justification for using the WACC is that it is simpler to use as compared to estimating a given project's risk and cost of capital and therefore less prone to manipulation. Another reason would be that all projects within the company have a similar risk profile.

But that simplification is value destroying. ${ }^{22}$ It is the WACC of the project itself that one must use, with its particular D/E capital structure ratio and its own cost of debt and equity, reflecting its particular cost of capital. The overall financing of the firm and the evaluation of investment projects are two different responsibilities in private corporations. Even if holders of additional debt raised to finance a given project have recourse to the whole cash flows of the firm and determine their required interest rate and loan condition accordingly (through rating the company's debt rather than what would be the "project's debt"), it remains that the optimal investment policy of the firm must be linked to each project risk profile and particular cost of capital and discount rate.

22 Kruger, P., Landier, A., and D. Thesmar, "The WACC Fallacy: The Real Effects of Using a Unique Discount Rate", The Journal of Finance, Vol. LXX, No.3, June 2015. The authors verify investment biases empirically and measure the value destruction caused by this fallacy. 
In either case, it might not be a serious problem for a large company making a lot of smaller investments, but it can be a big problem when you throw into the mix one single massive investment, with a complex array of new and long-term risks.

In using a concept of WACC as the cost of capital in evaluating a Crown corporation project, one must determine the proper "interest rate on the debt" and the "return on equity", which enter into the calculation of the WACC. Those two factors must be evaluated at the project level, hence in relation to the risk of the project being considered and its particular cost of capital and discount rate. If one uses the overall Crown Corporation cost of debt or Government cost of debt financing as the cost of debt, which together with an estimated cost of equity determine the WACC, one makes a second error: besides improperly using the WACC itself directly in investment evaluation (the first error), the WACC used itself would be underestimated (the second error): if the WACC, which should not be used, is nevertheless used, then it must be estimated properly with proper estimates of the cost of debt, the cost of equity, and the proportions of each that are appropriate for a project with that particular risk profile.

In the overall financing of a private firm, the cost of debt and the cost of equity are both market driven and represents the risk the firm's lenders and stockholders are supporting and facing. Only the error related to using the wrong WACC is made (insofar as the WACC of the firm is used rather than the WACC of the project). In the case of a public firm, which benefits from the fact that the government can raise taxes to repay its debt obligations, using the interest rate at which the government can finance its debt means that a second error is made namely the error of using an interest rate that hides the significant risk supported by taxpayers. Not only the WACC fallacy is present but the interest rate used in calculating the WACC is underestimated, thereby reducing the WACC and generating further distortions in investments and losses of value.

My third comment relates to two further mistakes identified in the C.D. Howe Institute Report (Commentary \#388) that are also relevant in the present BC Hydro Site C case. Hence a brief comment is warranted.

The mistake made by using a single cost of capital in assessing a project when it is dependent on several different sources of risk comes from the fact that, in such a case, the net present value (NPV) methodology is at variance with, that is, violates two fundamental principles of value creation in modern finance, namely the principle of additivity ${ }^{23}$ and the principle of no arbitrage

\footnotetext{
${ }^{23}$ The additivity principle states that the value of a portfolio of independent projects must be equal to the sum of its constituent projects. We must, therefore, be able to evaluate a sequence of cash flows broken into several components by the sum of the evaluations of these various components.
} 
opportunities. ${ }^{24}$ The use of a single discount rate for a project's net cash flows is the main problem, even when the discount rate is risk-adjusted. We cannot avoid considering separately the cash-flow components that are dependent on different sources and levels of risk and assigning them a risk premium of their own.

The other mistake is related to the fact that when managers may intervene in the development, implementation, and timeline of a project by reacting to a changing and volatile environment, the traditional NPV must be replaced with the real option valuation (ROV) that integrates the value of managerial flexibility in the project's value. This is because traditional NPV implicitly assumes that a company investing in a project passively holds the underlying assets for the life of the project. NPV therefore neglects the value of active management.

In the presence of managerial flexibility, investments, in particular strategic investments, can be seen as portfolios of real options that managers exercise at the appropriate time. Managers are expected to respond to future events and market developments as well as to changes in the intensity of competitive forces. The NPV methodology does not have the flexibility to account for managers' expected flexibility options. These options are similar to financial options but are generally more complex. However, they can be evaluated using a similar methodology. Neglecting them produces a bias, usually downwards, in project value.

In the case of $\mathrm{BC}$ Hydro Site $\mathrm{C}$, it is clear that management flexibility in controlling or adapting the development, implementation, and timeline of the project in reaction to a changing and volatile environment will raise the value of the project as well as the value of the alternative projects. Ascertaining these relative flexibility values cannot be neglected. It is complex but can be done in a rigorous manner and should be done.

My fourth comment is that one must remember and keep in mind that there are two broad groups of risks: one group I will call project management risks and one group I will call market risks.

Project management risks are risks that managers can mitigate through better resource and schedule planning, better inventory management, better surveillance of construction and operations, and more generally through better incentives and incentives alignment fostering proper cooperation and exchange and use of information throughout the chain or network of

\footnotetext{
${ }^{24}$ An arbitrage opportunity can be defined as an investment strategy at no cost (no net-cash outflow) that promises a positive return in some states of nature while having a zero probability of loss. The principle of no arbitrage states that in developed markets populated by rational agents, arbitrage opportunities for all practical purposes should be rare and of short duration or non-existent. If an arbitrage opportunity arises, the agents would exploit it immediately, and it would quickly disappear. In other words, "there is no free lunch," especially in the world of public or private finance.
} 
operators, clients and suppliers, and stakeholders. One example suffices to characterize such project management risks: if the resources dedicated to achieving a given task on time are insufficient in quantity and/or quality, there is a serious risk that the objective will not be met. But this is not really a risk, but a certitude!

Market risks are different. They relate to the impact of the overall economic outlook on the financial results of the project. The economic outlook, with alternating periods of favorable conditions (expansion) and unfavorable ones (slowdown or recession) will affects more or less severely the benefits and costs of the project. The risk level is typically measured as the beta factor, which measures the relative covariance between the project's financial returns from the net cash flow results and the overall broad market returns over the variance of market returns. This beta factor, which is a measure of the quantity of risk, is combined with the market price of risk or risk premium and the risk free or pure time preference rate to determine the appropriate discount factor to apply to the expected cash flows generated by the project. A project, a firm, and an industry can be characterized by their respective beta factor. ${ }^{25}$

My fifth comment relates to the seemingly counterintuitive result that riskier costs, discounted at a higher discount rate, will have a present value that is smaller than less risky costs discounted at a lower discount rate. Again for reasons of providing a reasonably integrated analysis of BC Hydro Site C project, some elements of Section 4 (Infrastructure Ontario) are briefly repeated here. In choosing between two projects with identical revenue or benefit streams and similar expected costs, the Discounted Cash Flow criteria will favor the riskier project. It is sometimes or often claimed that this result is counterintuitive. The result may be counterintuitive, but it is nevertheless correct!

The reason why this so-called counterintuitive result is correct is that risky costs, assuming that the systematic riskiness of costs is properly measured through the costs beta factor (see my fourth comment just above), act as a form of insurance against the fluctuations of the market: if costs are systematically riskier, it means that they are high when market returns are high and low when such returns are low. This makes the riskier project more valuable and should not lead to manipulations to avoid this result. ${ }^{26}$

\footnotetext{
${ }^{25}$ See for instance http://pages.stern.nyu.edu/ adamodar/New Home Page/datafile/Betas.html

${ }^{26}$ Infrastructure Ontario (IO) has for instance developed a methodology to improperly correct the proper result through value-destroying manipulations (or "comprehensive risk assessment" in IO terminology) to "avoid this result." In doing so, 10 goes against the lessons of modern finance and contribute to destroy value through improper project choices. See the C.D. Howe Commentary \#388 for more on this.
} 
BC Hydro falls into this trap as noted in its response to IR 2.50.2 27 : “In contrast, BC Hydro's analysis compares the costs of portfolios of multiple alternative resources and as such uses the discount rate to compare the annual costs of portfolios based on the 'time preference' of ratepayers. If in portfolio PV cost analysis one were to apply a higher discount rate for portfolios of similar cost but higher risk, the distorted outcome would be that a riskier portfolio would result in lower PV costs and appear to be the preferred outcome."

It appears that the preference of BC Hydro for sensitivity analysis to account for risk is misplaced. Sensitivity analysis allows to illustrate how different factors may affect the value of projects. As such it is a complement illustrative tool but not a substitute for the risk adjusted discount rate in project evaluation. The confusion is clear when BC Hydro writes: "BC Hydro believes that the sensitivity approach provides a more transparent view of the risks to the projects and the impact of each as opposed to a subjective and blanket change in the discount rate." 28

BC Hydro fails to properly consider the differential risks of BC Hydro projects and IPP projects when it writes: "The discount rate used for evaluations should be the same for BC Hydro projects and IPP projects. While it is possible to vary discount rates by adding a further projectrelated risk premium to reflect project-specific risks, the BCUC found that project-specific risks should be assessed through sensitivity analysis and contingencies as BC Hydro has done in its filing." The only situation where this approach is warranted is when cash flows have been transformed into certainty equivalent cash flows to be discounted at the risk-free rate. ${ }^{29}$ This does not appear to be the case here.

\section{Concluding comments on BC Hydro Site C project}

The financial analysis completed for BC Hydro's Site C project shows a number of errors, primarily related to the inappropriate accounting and allocation of risk (in its many forms). While the general financial methodology may be correct, the application and specific values used to complete the financial analysis is seriously flawed. These errors expose BC citizens to potentially large losses of value, possibly hundreds of millions of dollars, if not more, without any compensation for the risks they are being asked to bear.

\footnotetext{
${ }^{27}$ DOC_90351_F1-5_BC Hydro_Site-C-Submission, IR 2.50 .2

${ }^{28}$ DOC_90351_F1-5_BC Hydro_Site-C-Submission, IR 2.50 .2

${ }^{29}$ See Marcel Boyer and Éric Gravel (2006), "Évaluation de projets : La valeur actualisée nette optimisée (VAN-O)," Insurance and Risk Management, 74(2), July 17, 2006, 163-185.
} 
For example, given the difference between a 3.4\% interest rate currently being applied to Site C and a real world (i.e. risk accounted) properly defined WACC of $8.8 \%$ as suggested here, the overall effect of this difference, including aforementioned errors, results in a significant present value bias that appears to have led to the selection of Site $C$ as the least cost option.

\section{AuCtioning BUSINESS SUPPORT PRograms}

In the same vein, we can be suspicious of government grants, loans, loan guarantees, and even of equity investments in private firms - particularly to the extent that they rely on the aforementioned rationale that the government faces lower financing costs than the private sector.

One transparent way to proceed in the context of this type of program would be to auction off specific government assistance projects, thus transferring to a local or international private financial consortium, in as short a time as possible, responsibility for honouring the grant, loan, loan guarantee, or the capital injection. This consortium would assume responsibility for the outlays and benefit from repayments at levels and under conditions determined by the government project, in exchange for a premium paid by the government to the winning consortium.

As the conditions attached to these assistance, subsidy, or equity participation projects are naturally more favourable for the companies than similar financing obtained on financial markets, this premium would represent the compensation required by the consortia called upon to take over the government's commitments.

From the government's perspective, the smallest premium that would emerge from the auction would be the best estimate of the public cost of the assistance or support project, i.e. the expenditure to be recorded in the budget. This premium could take various forms: a one-time payment or constant or variable annual payments stretched out over time, or options for the project to revert to the government. Alternatively, the government could choose to take out an insurance policy with private insurers / investors, who would assume the risk of repayment of the assistance previously borne by taxpayers.

It is neither the role nor the jurisdiction of the government to play stockholder with taxpayers' money. The main advantage of auctioning government assistance is to nip in the bud the ubiquitous risk of a creeping crony or collusive capitalism at the expense not only of the beneficiaries and taxpayers, but also of the companies themselves, no matter how grandiloquent the intentions expressed by the government and other stakeholders. 
There are better ways to ensure the incentive-based development of successful businesses by providing them with tools to use to manage the real and systematic risks they face and might embody.

\section{CONCLUSION}

The management of public funds have been more or less responsible or ethical in the last decades. After a push for balancing budgets or at least keep deficits within a relatively small margin measured as a cumulative $\%$ of GDP or as a given $\%$ of the budget itself, the bottom fell out with the Trump administration in the US and other "populist" government across the world, including Canada.

A significant step in that direction occurred with the advent of the COVID pandemic. All countries increased significantly their government deficit in order to alleviate the dire effects of the pandemic on different economic sectors and their workers. Canada for instance went from an expected 2020 deficit of some $\$ 25$ billion to an astonishing one of close to $\$ 400$ billion at the federal level only, hence to even larger number globally if one adds deficits of provincial and municipal governments. The dominant vision is that it does not matter too much as interest rates on government borrowing are seemingly very low.

But the true interest rate is much larger than it appears even in these "uneconomic" times. Most of the borrowing is obtained from central banks, hence through virtually printing money. Why? Because private lenders, usually keen to profit from the good conditions of lending to the government (with whatever risks transferred to taxpayers, let uncompensated), do not rush to buy the government bonds. Why? Because first, the risk is too high and second, letting the central banks print money for the governments avoid the bad publicity of forcing the repayment of public debt. The central banks are not true lenders as they could simply erase government debt from their assets.

The huge increase in public debt may send the signal that debt is good and apparently cheap. If governments could implement such a large recourse to debt to fight COVID-19, why not use similar recourse to debt also to overcome climate change, to invest more in our health and education sectors at all levels, to meet our significant needs in infrastructures, etc. Remember the warning of the dismal science: Needs are infinite, but resources are limited. The ensuing drop in fiscal discipline, rather than moving us towards a more cooperative world, is the seed of forthcoming aggressive political battles and social disruption.

Unfortunately, too many government departments and organizations suffer from the same disease: they turn out to be political entities with an aversion to rigorous financial principles. The way to achieve an optimal investment portfolio is to follow evaluation methodologies that are rooted in sound economics and finance and to apply them as rigorously as possible. One 
thing is sure: hiding costs by transferring risks to taxpayers without proper real or virtual compensation one way or another is not the way to do it.

Miscalculation, misinformation, mismanagement, and fallacious analysis will eventually backfire, as always. 